\title{
Age Heterogeneity of STEM Educators
}

\author{
Tatiana V. Sibgatullina ${ }^{1}$, Vyacheslav V. Utemov ${ }^{2 *}$, Alexander A. Galushkin ${ }^{3,4}$, Natalia A. Zaitseva ${ }^{5}$ \\ ${ }^{1}$ Kazan (Volga region) Federal University, Kazan, RUSSIA \\ ${ }^{2}$ Vyatka State University, Kirov, RUSSIA \\ ${ }^{3}$ Peoples' Friendship University of Russia (RUDN University), Moscow, RUSSIA \\ ${ }^{4}$ Stolypin International Institute of Informatization and Public Administration, Moscow, RUSSIA \\ ${ }^{5}$ Plekhanov Russian University of Economics, Moscow, RUSSIA
}

Received 15 October 2018 - Revised 21 January 2019 • Accepted 3 March 2019

\begin{abstract}
One of the ways to improve the quality of math and natural science education is to develop the pedagogical community of STEM education. On the one hand, according to the forecasts, an increase in the number of students and teachers is expected by an average of $20 \%$ in both Russia and worldwide. On the other hand, there is definitely some specificity in the pedagogical community as compared with any other labor collective, since the pedagogical community develops alongside with the student one. In this perspective, the age heterogeneity of the teaching staff is of particular relevance. Consequently, the key point in the management of math and natural science education is the analysis of the age structure of STEM educators. The following subjects are taken to conduct a further analysis of STEM education: mathematics, handicraft, physics, biology, and chemistry. Accordingly, the purpose of the article is to analyze and forecast the heterogeneous development of the age structure of STEM teachers. The authors of the article justify the necessity for changes in the personnel policy on the basis of the assessment of the capacity of the teaching staff of STEM education in schools of the European part of Russia. The leading research approach is the method of the normal and natural distribution of age groups in the structure of the STEM education pedagogical community. As a result of a study conducted in 569 schools of the European part of Russia in 2016-2018, the authors of the article have found out the following: the average age of STEM school teachers in the European part of Russia is 6.8 years higher than the average age of teachers in Russia; there is a significant shortage of STEM teachers aged under 35; the average rate of the teaching load of a STEM school teacher in an academic subject is 0.72 , but the load is distributed very unevenly, math teachers having the highest teaching load. The theoretical significance of the research lies in its contribution to the development of scientific ideas concerning the age heterogeneity of STEM school teachers. The research results can be used in building development trajectories of STEM education teaching staff by implementing a series of managerial and organizational measures to achieve the normal state of the age structure of teachers.
\end{abstract}

Keywords: STEM education, age heterogeneity of teachers, age structure of the pedagogical community, seniority of teachers, normal distribution of age groups

\section{INTRODUCTION}

The development of the regional pedagogical community largely determines the quality of education and the success of graduates of educational institutions at all levels of education (Dmitrieva et al., 2015; Filatov et al., 2018; Firsova et al., 2018; Novikova et al., 2018; Oborsky et al., 2018; Petrovskaya et al., 2016; Shcherbakov et al., 2017;

(C) 2019 by the authors; licensee Modestum Ltd., UK. This article is an open access article distributed under the terms and conditions of the Creative Commons Attribution License (http://creativecommons.org/licenses/by/4.0/). \sibgatullinatatiana@yandex.ru $\boldsymbol{\nabla v}$ v_utemov@vyatsu.ru (*Correspondence)

\alexander.galushkin@yandex.ru $₫$ zaitseva-itig@mail.ru 


\section{Contribution of this paper to the literature}

- The study defined the age structure of the STEM school teachers in the European part of Russia. The average age of STEM teachers (teachers of mathematics, handicraft, physics, biology and chemistry) is 51.8. It should be noted that the normal value of the average age is 45 , and the average for the regions is 48.1 years. The group of STEM teachers under the age of 35 makes up only $11 \%$ against $33 \%$ characteristic of the normal distribution.

- It has been determined that the optimal age distribution of teachers should be close to the normal distribution. The coefficient of deviation from the normal age distribution of STEM teachers reaches up to $50 \%$ which is significantly higher than the average coefficient for all teachers which does not exceed $32 \%$.

- The analysis of the teaching load of STEM teachers with regard to the subject has shown that the load of teachers of different subjects is uneven. Thus, the rate of the load of math teachers in the region averages out at 1.0; the average load rate of teachers of handicraft, biology and physics is 0.65 ; the one of teachers of chemistry is 0.56 .

Zaitseva et al., 2017, 2018). The process of teacher training is multistage, but it should facilitate updating of professional teaching activities at each stage. It is important that it is provided with a transparent mechanism of interaction of all stakeholders (education authorities at various levels, teacher training institutions, general education institutions and other stakeholders) (NGPU, 2016). This mechanism should mainly rely on the existing age structure of teachers in each school subject (Faleeva et al., 2017; Lubnina et al., 2016; Rudenko et al., 2015). There is a quite limited number of applicants who want to get pedagogical qualifications, and neglecting the current situation concerning the age of teachers can lead to an inefficient allocation of state-financed places to teacher training institutions, and, consequently, to an increased risk of a shortage of subject teachers in the relatively short term. Math and natural science education is given special attention to when managing the school education. In this regard, it is important to analyze the age structure of STEM educators. Thus, we have taken the following academic subjects to conduct a further analysis of STEM education: mathematics, handicraft, physics, biology, and chemistry.

Additional risks of irrational allocation of state-financed places to higher education programs of STEM teacher training are associated with the lack of a comprehensive analysis. The analysis of the shift in the schoolchildren population with regard to the year of study and projecting the teaching load in STEM-subjects for several years in advance may become a normative forecast method. But if we take into consideration that, by 2020, the number of students in general education institutions only in one entity of the European part of Russia will reach up to 128.2 thousand people (according to the Center for Social Forecasting and Marketing, 2013 (Rosstat, 2016)) or 137.4 thousand people (according to the Institute of Sociology of the Russian Academy of Sciences, 2015 (TsSP and M, 2017)), then an increase in the number of students will be by $7 \%$ as compared to 2016. It is necessary to check this growth against the projected number of STEM subject school teachers by 2020. Thus, the assessment of the age structure of the STEM education teaching staff of schools of the European part of Russia is a necessary condition to optimize the teacher training process and identify the development trajectories for the STEM schools teachers in the European part of Russia.

At the end of 2016, a similar study was conducted using the example of the Kirov region. The study results contain an objective generalized assessment of the structure of the teaching staff of general education organizations by age, education level, subject; the study also offers a projected estimate of the demand for teachers in the region until 2022 (Pugach \& Utemov, 2016).

The analytical report based on the study results contained the data justifying the fact that it was necessary to take management decisions in the field of personnel policy in the sphere of education in the region (Kvon et al., 2017, 2018). Thus, for example, the most critical age groups of teachers are teachers of physics, chemistry, geography, biology, art and drawing, the Russian language and literature. On the other hand, there is a significant shortage of male teachers. Only $11 \%$ of all school teachers are male. The research conducted by McGrath and Bergen (2017) shows that there is a decline in the share of male teachers worldwide, however, the development of STEM education shows a particularly strong dependence on male teachers (Kraker-Pauw et al., 2016). It should also be noted that one more reason for decreasing numbers of male teachers is that employers are more inclined to offer administrative positions to them rather than women (Wagner, Rieger \& Voorvelt, 2016).

The results of the study (Pugach \& Utemov, 2016), however, did not contain any conclusions concerning the STEM teachers, neither did they analyze the structure of the teaching load taking the subject into account.

In the summer of 2018, Minin University made a comparative analysis of the natural development of the age structure of the pedagogical community and gave a forecast of its development for the regions of the Russian Federation until 2050 in "Age structure of the pedagogical community: analysis and forecast of development: an analytical report" (Fedorov et al., 2018). As the analysis is of a generalized nature, we carried out an additional analysis in 2017-2018 the results of which are presented in the article. 


\section{LITERATURE REVIEW}

The domestic and foreign studies devoted to the development of pedagogical communities with respect to age heterogeneity are rather sketchy and fragmented.

Kuo et al. (2011) carried out a prognostic analysis of the proportion of young and aged teachers at the beginning of each school year. Oerke and Bogner (2010) describe in their study the importance of taking into account the age characteristics of the teaching team and their influence on the education process. There are a few studies describing ideas concerning the structural constraints (age, disability, ethnicity and gender) which hinder teaching careers (Cau-Bareille, Teiger \& Volkoff, 2019; Wilson et al., 2006). M. Sari (2012) writes in her article that female teachers take on their gender role of "being a mother" in their teaching practice which can influence teaching both positively and negatively. On the other hand, male primary teachers can have a greater educational effect on students (Bullough, 2015). At the same time, having a female teacher improves girls' academic performance in math (Xu \& $\mathrm{Li}, 2018)$.

Taking into account the age characteristics of the teaching team is an important aspect in managing the teaching staff. Thus, Zhou et al. (2011) make a conclusion that middle-aged teachers are more motivated to develop professionally; as teachers become older, their motivation appears to be noticeably reduced. The phenomenon of the teaching staff ageing is also characteristic of higher education. Thus, the average age of teachers in French universities is over 49 years. Roschnik et al. (2004) argue that there is a need for young university teachers, increasing their number may give a boost to educational and research activities. Some studies on the age structure of the teaching team also describe the structure of working capacity in relation to the age of teachers. For instance, only $4 \%$ of Finnish teachers aged over 45 have poor working capacity. However, the lowest level of working capacity among all teachers of this age is characteristic of teachers of vocational education institutions and teachers of special education (remedial) schools (Kinnunen, Parkatti \& Rasku, 1994).

Seibt et al. (2015) conducted a research on mental abilities of two groups of female teachers (the first group is teachers aged under 45; the second group is teachers over 45 years old). The results showed slight differences in favor of younger teachers. It is stated that there are some minor differences in respect to coherence, susceptibility to stress and health complaints. This group of scientists concludes that some components of the mental ability of teachers suffer age-related changes. At the same time, continuous training allows maintenance or an improvement of mental ability at any age (Seibt et al., 2015). On the other hand, constant overload and stress characteristic of the teaching activity can gradually lead to declining health of the nervous system of female teachers with age (Burumbayeva et al., 2018). Age trends, although not clear cut, showed greater tension for older teachers (Powell \& Ferraro, 1960).

Some research is devoted to how teachers respond emotionally to educational change at different ages (Hargreaves, 2018). According to Etherington (2011), the attitude of older teachers to change depends on how well established their careers are. Tumova (2012) makes a similar conclusion, stating that the effects of age and length of professional experience on teachers' attitudes to the curricular reform and its implementation are not as strong as they might be expected. Some research has shown that experienced teachers have noticeably lower levels of anxiety (Aslrasouli, Saadat \& Vahid, 2014). It is worth mentioning that there are also critical reviews stating that the introduction of innovations into the educational process can lead to decreasing quality of education. In this regard, an adequate response to innovation could be useful (Pedro et al., 2018). Undoubtedly, it is necessary for teachers who have different seniority to implement changes in teaching from time to time (Dare, Ellis \& Roehrig, 2018; Lynch, 2018). Some research proves that the practice of sport and physical activities and leisures can have a protective effect against burnout syndrome (Moueleu Ngalagou et al., 2018). Hildebrandt and Eom (2011) make a conclusion that teachers of different ages have different motivators for teacher professionalization and it should be taken into account.

Gampel and Ferreira (2017) analyzed adolescent evaluations of ageing teachers' voices. For example, teenagers showed a friendlier attitude to teachers whose voices were more expressive. Ahlander, Rydell and Lofqvist (2011), analyzing the influence of the age of math teachers on the quality of their performance, come to the conclusion that teachers who experience problems with voice also face problems in teaching. Ageing teachers suffering from the burnout syndrome often experience voice disorders (Mota et al., 2018).

Some studies analyze work ability and vitality of teachers of different age groups. It is found out that $24 \%$ of teachers of the younger age group and $49 \%$ of the elderly teachers show a poor/moderate work ability, which indicates an urgent need for measures for improving work ability (Freude et al., 2005). On the other hand, the length of experience of some teachers (special education programs, vocational training institutions, pre-school education, etc.) has a significant effect on the quality of their performance (Selzer King et al., 2018; Sheridan et al., 2018). The study conducted by Sasa, Borosb and Bonchisc (2011) reveals the dependence of the professional burnout of the teacher on the level of education where the teaching activity is performed. 


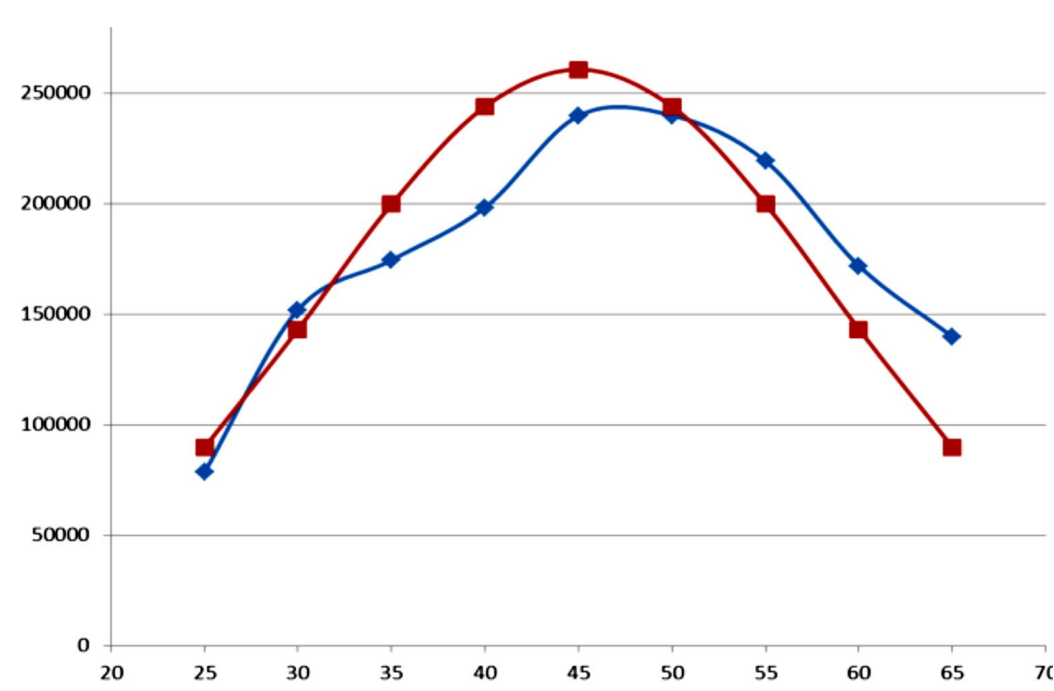

Figure 1. Age distribution of the RF teachers

Although knowledge is an integral part of the professional competence of teachers, it is not limited to knowledge only. Skills, relations and motivational incentives also contribute to mastering educational technologies. Blömeke and Delaney (2012) developed a model that identifies cognitive abilities and affective-motivational competencies as the two main components of the professional teacher knowledge. The first component contains professional knowledge, methodological knowledge (methods for teaching a particular subject) and general pedagogical knowledge. This component can be analyzed by assessing the students' opinions (Gargallo et al., 2018; Moe et al., 2019). The second component includes motivation, self-regulation and professional beliefs about teaching, and the content of the subject. It should be noted that the issue of the professional attitude to and methods for teaching a particular subject by various teachers is a separate area of research (Demonty, Vlassis \& Fagnant, 2018; Lingo et al., 2018).

\section{MATERIALS AND METHODS}

\section{Theoretical Framework}

The study of the heterogeneity of the age structure of STEM educators is based on the method of the normal and natural distribution of age groups.

The normal distribution contributes to the stable functioning of the education system, retaining the balance and offering a possibility for an educational institution to both develop and preserve traditions at the same time. The natural distribution is based on the invariant nature of the development of the pedagogical community where each age group is represented by an equal number of members.

In the study, the optimal distribution of teachers by age in any pedagogical community should approach the normal distribution (Gauss distribution) having properties characteristic of the range from 25 to 65 with the spacing equal to 5. Thus, the distribution of the Russian Federation teachers by age is presented in Figure 1.

The red line is the normal distribution (Gauss distribution); the blue line is the natural distribution.

The analysis of the distribution of age groups in the structure of the pedagogical communities of the regions as of 2016-2017 has shown the deviation of the distribution of age groups in the direction of the middle and senior age groups.

By comparison, the age distribution of STEM teachers is presented in Figure 2. 


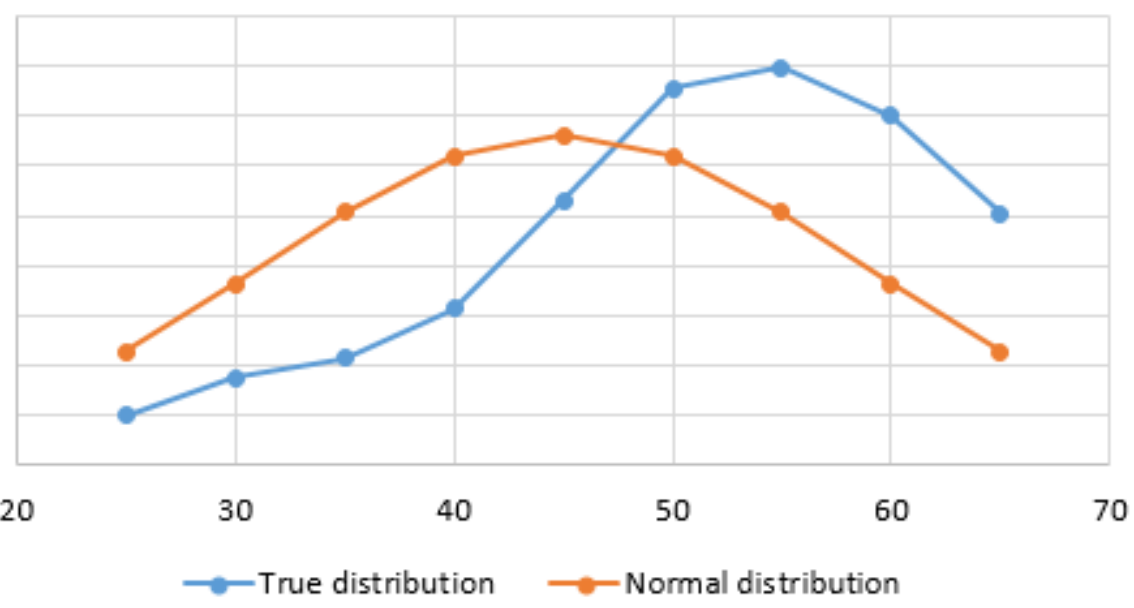

Figure 2. Age distribution of STEM teachers

It is evident that:

- the average age of STEM teachers of the European part of Russia (the peak of the natural distribution) is 6.8 years higher than the average age of the teachers in the Russian Federation;

- there is a significant shortage of teachers aged 30-45 in the region;

- the number of teachers in the region who are over 45 exceeds the norm dramatically.

Thus, the age structure of STEM teachers in the regions should be brought closer to the normal distribution.

\section{Research Methods}

To analyze and forecast the development of heterogeneity of the age structure of STEM school teachers in the European part of Russia, we employed the following methods: collecting empirical evidence by questioning the administrative personnel of the educational institutions; modeling the normal and natural distribution of age groups in the structure of the pedagogical community of STEM education; statistical processing of the experimental data.

\section{Experimental Infrastructure}

The research data to analyze and forecast the development of heterogeneity of the age structure of STEM teachers were collected, analyzed and generalized on the basis of 569 Russian schools (2016-2018):

- $\quad$ The research data were collected by means of questioning the administrative personnel of the educational institutions. The general education organizations of all educational districts of the regions were included in the study. The questionnaire consisted of 5 sections.

- The expert analytical assessment of the teaching load of the teaching staff of the educational institutions was conducted by means of the statistical processing of the experimental data. The results of the assessment were discussed with teachers of mathematics, handicraft, physics, biology and chemistry at seminars and round table discussions held within the framework of scientific and methodological workshops at the Vyatka State University (more than 200 participants annually).

- The results have been presented in the form of reports and presentations at scientific conferences and seminars of various levels, including international ones; they have also been published in collections of scientific articles and scientific journals.

\section{Stages of the Research}

The research consisted of four stages.

At the first stage, the state of the research problem in the theory and practice of teaching STEM subjects at school was investigated. The review of psychological, pedagogical and methodical literature on the problem of the research was carried out; conversations with teachers and the administrative personnel were held; the experience of teachers and the administrative personnel was examined and analyzed in order to predict the development of heterogeneity of the age structure of STEM teachers. 


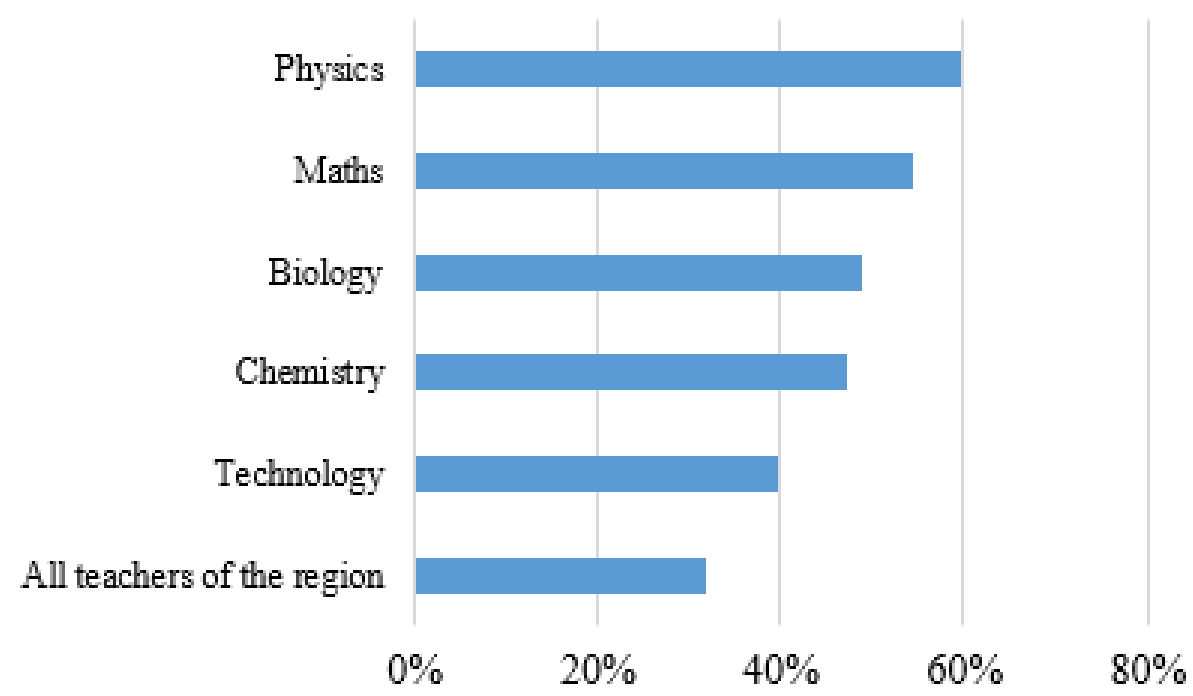

Figure 3. Coefficient of deviation from the ideal state for each group of STEM teachers in percentage

The methodological approach to how to analyze and forecast the development of heterogeneity of the age structure of STEM teachers was developed at the second stage of the research. The working laws were determined and the distribution of age groups in the structure of the pedagogical community was identified. The results of this stage were reported and discussed at conferences of various levels and seminars devoted to teaching school subjects.

The third stage of the research was carried out along with the second one. The administrative staff of 569 educational institutions were surveyed. They were asked to fill in a questionnaire consisting of 5 sections.

At the fourth stage, the expert analytical assessment of the capacity of the teaching staff of the educational institutions was carried out by means of the statistical processing of the experimental data. The research data on STEM teachers were generalized to form the grounds for justifying the need for management decisions in the personnel policy in the sphere of STEM education.

\section{RESULTS}

\section{Differences in Distribution of STEM Teachers by Age with Regard to the Subject Taught}

To identify the distribution of STEM teachers by age with respect to the subject taught, we have built the respective graphs. In order to compare the deviation, we calculated the coefficient of deviation from the ideal state for each group of teachers. The list of groups of teachers ranked by deviation is presented in Figure 3.

It is evident that there are significant differences in the age distribution of STEM teachers with respect to the subject taught. The deviation exceeds $50 \%$, which is significantly higher than the average coefficient for all teachers, which is usually not higher than $32 \%$.

\section{Differences in the Distribution of STEM Teachers by the Structure of the Teaching Load with Regard to the Subject Taught}

The collected data also make it possible to analyze the structure of the teaching load for the teachers in the region. Our calculations show that the average rate of the load for a school teacher in one subject is 0.70 . But the rate of the load for teachers of mathematics is 1.0 on an average, the rate for teachers of handicraft, biology, physics is 0.65 , for teachers of chemistry -0.56 .

The total share of teachers in the structure of the load is presented in Figure 4: it shows the percentage of teachers having the rate of the teaching load over $1(>1)$, less than $0.5(<0.5)$ and in the range from 0.5 to $1.0(<1)$. 


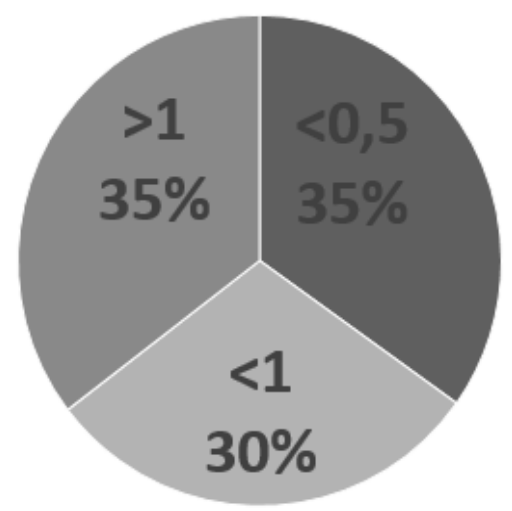

Figure 4. Structure of the teaching load for STEM teachers

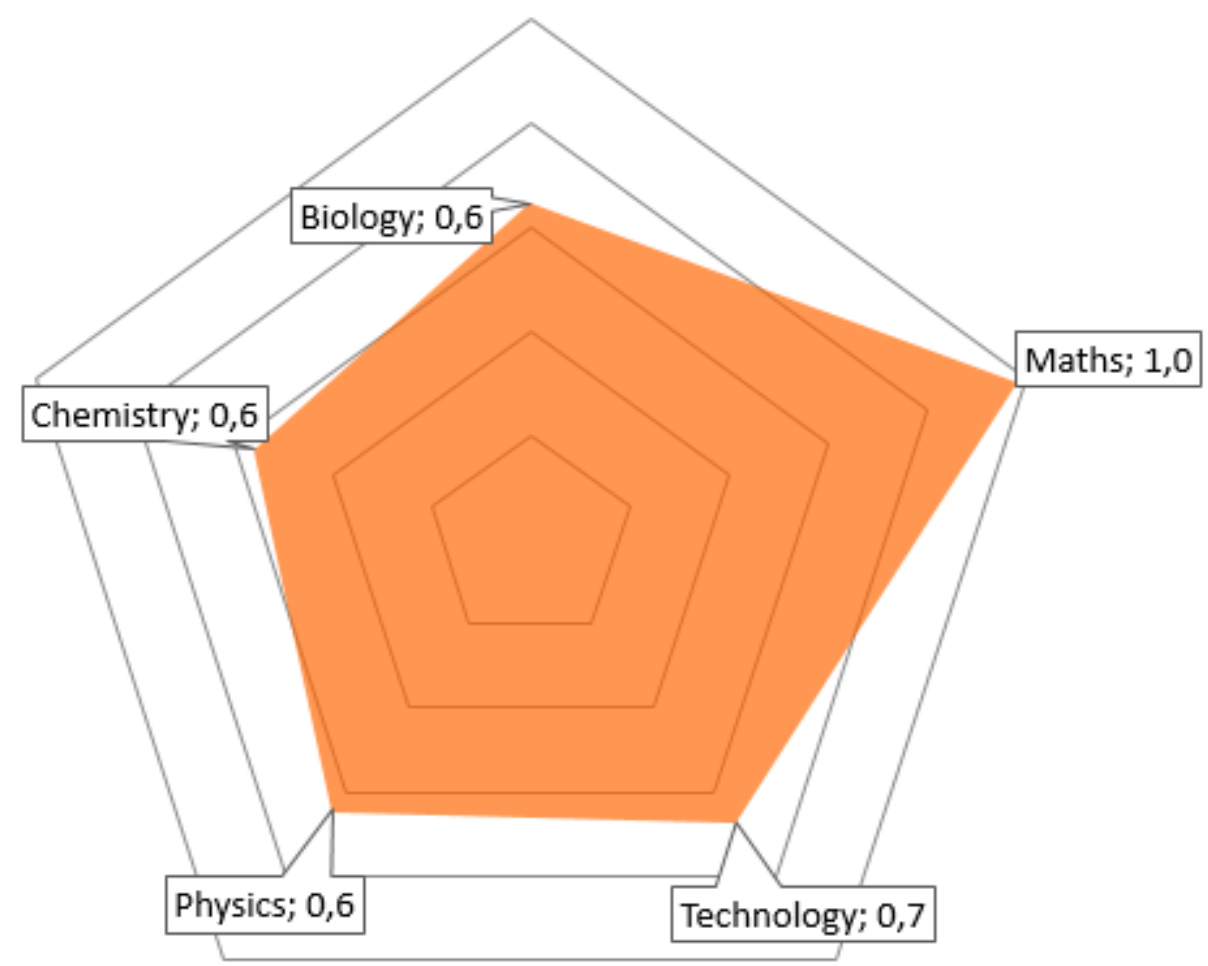

Figure 5. Teaching load for STEM teachers

The analysis of the structure of the teaching load with respect to the subject taught shows that the shares of STEM teachers having the rate of the load over 1.0, from 0.5 to 1.0 and less than 0.5 are approximately equal.

Another value that was calculated is the weighted average of the rate of the teaching load with respect to the subject taught (Figure 5).

It is seen that math teachers have the highest teaching load. Thus, the data obtained should be taken into consideration when combining the major subjects to train teachers at educational institutions.

\section{Differences in the Average Age Distribution of STEM Teachers with Regard to the Subject Taught}

The weighted average age of STEM teachers with regard to the subject taught is presented in Figure 6 . The normal value of the average age is 45 years, and the average for the region is 48.1 years. 


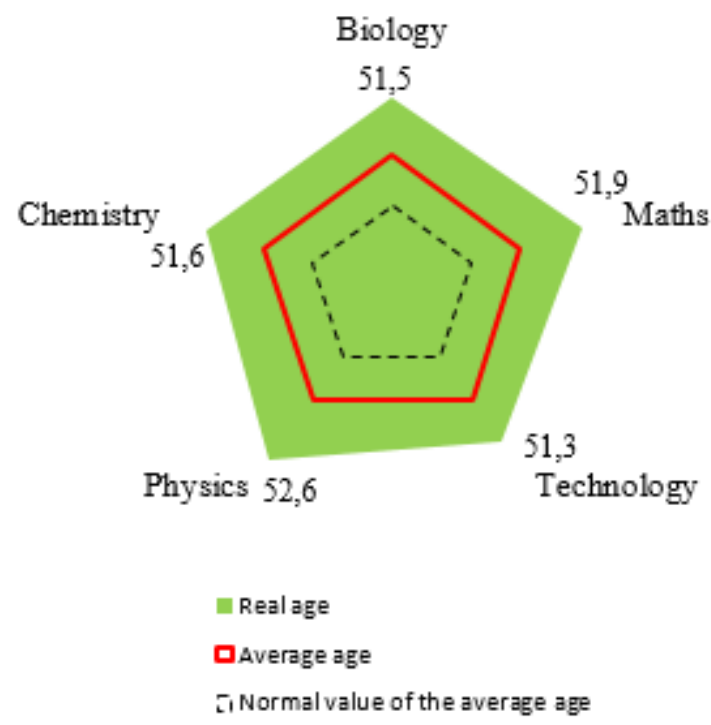

Figure 6. Average age of STEM teachers with regard to the subject taught

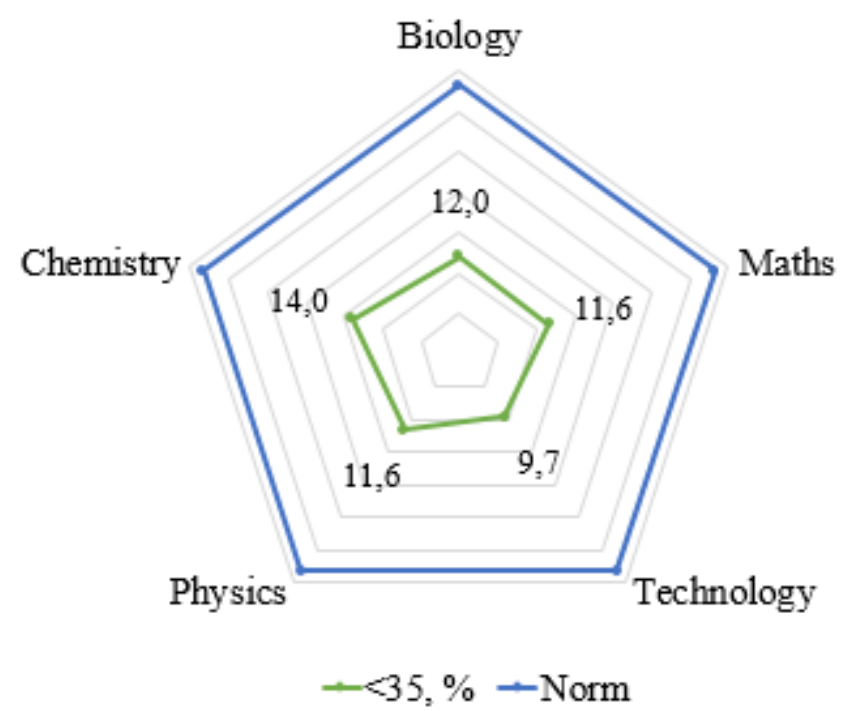

Figure 7. The share of STEM teachers under 35 years old with regard to the subject

The situation seems to be the most problematic with the teachers of physics.

Currently, the only quality characteristic of the age structure of the pedagogical community is the relative share of the number of teachers aged under 35. Thus, the indicator "the share of the number of teachers aged under 35" is established as a monitoring indicator for educational institutions by Order of the Ministry of Education and Science of the Russian Federation No. 955 of September 22, 2017 (the Ministry of Education and Science of Russia, 2017). The results of the analysis of these indicators are given in Figure 7.

It should be noted that the indicator of $33 \%$ of teachers under 35 years old in the total number of the teaching staff is considered to be normal in the natural distribution (a blue curve in the figure). Thus, it is evident that the most critical situation is in the sample of teachers of handicraft, physics, and mathematics.

\section{Age Structure of STEM Teachers}

The age structure of the pedagogical community in this study is presented as nine age groups integrated into three larger age groups:

- young teachers - under 25, 25-30, 30-35 years; 


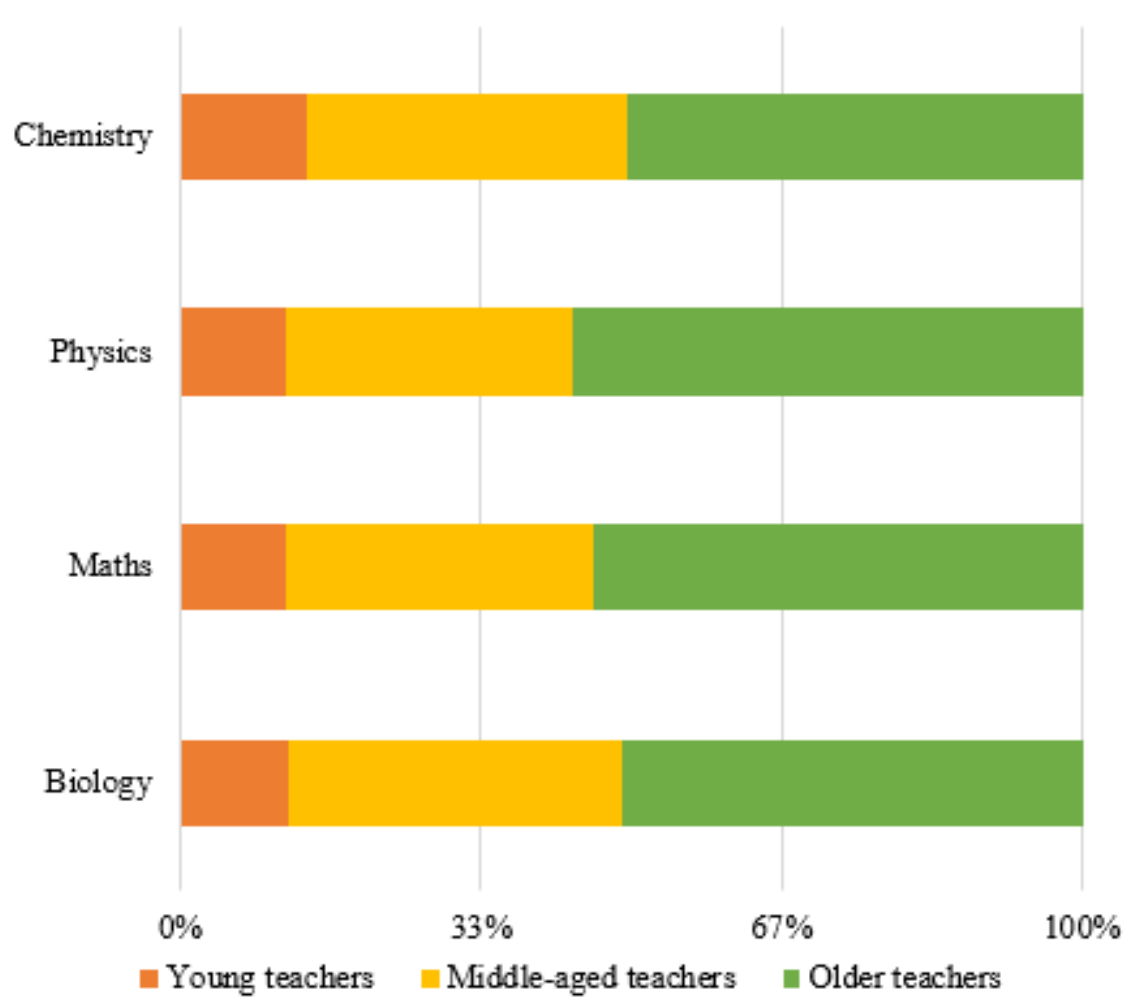

Figure 8. Age structure of STEM teachers by age groups

- middle-aged teachers - 35-40, 40-45,45-50 years;

- older teachers - 50-55, 55-60, 60 years and older.

The share of each age group of STEM teachers is shown in Figure 8. The analysis of age groups presented in Figure 8 confirms the previously stated conclusion, namely: the groups of teachers of biology, mathematics, physics and handicraft demonstrate the most worrying situation in the age structure of the pedagogical community.

\section{DISCUSSIONS}

The results of the study conducted in 2016-2018 in 569 schools of the European part of Russia demonstrate the following: the average age of STEM teachers is 6.8 years higher than the average age of teachers in Russia; there is a significant shortage of STEM educators aged under 35; the average rate of the teaching load of a STEM school teacher in one subject is 0.72 , but the load is distributed very unevenly. The teacher of mathematics has the highest teaching load. The results of the research make it possible to build the trajectory of development for the STEMeducation teaching personnel by means of implementation of a set of managerial and organizational measures to achieve the normal condition of the age structure of teachers.

On the one hand, the method of the normal and natural distribution of age groups in the structure of the STEM pedagogical community allows us to analyze the heterogeneous development of the age structure of STEM teachers in the region. On the other hand, it may become a key point in the management of mathematical and natural science education by means of modeling the projected development of the age structure of STEM educators.

Another important aspect is identifying the factors negatively affecting the age structure of STEM teachers and minimizing their influence. This issue can be considered separately.

\section{CONCLUSION}

Having made the correlation analysis of the data on the teaching load and age structure, having made calculations to determine the degree of dependence, we have come to the conclusion that middle-aged teachers have the most of the teaching load while younger teachers most often have a smaller volume of the teaching load. With regard to older teachers, it has been revealed that the volume of their teaching load is minimal. This fact highlights the critical character of growth of the share of older STEM teachers in the pedagogical community of the regions. 
The research results combined with the data of the Rosstat demographic forecast, for example, for the Kirov region for the period up to 2036, allow us to make a few more generalizations. (the Rosstat's demographic forecast for the Kirov region, 2018): reduced numbers of middle-aged teachers affect the volume of the teaching load most critically (teachers of the middle-aged group have on average a $30 \%$ higher teaching load than the teachers of the younger age group); the number of middle-aged teachers is decreasing at a faster rate than the number of children in the region which may exacerbate the problem of teacher shortage.

To sum up the analysis and forecast of the development of heterogeneity of the age structure of STEM teachers, it should be stated that there is a need for building a trajectory of development for STEM teachers by means of implementation of a set of measures aimed at achieving the normal condition of the age structure of the pedagogical community in the region.

The main trajectories of the development of the pedagogical community with respect to age heterogeneity may include the activities along the following lines:

1) managerial:

- open contests held by the regional educational authorities giving the right to conduct advanced teacher training courses;

- implementing the Mobile Teacher project;

- creating educational clusters;

- a transition from employer-sponsored admission to targeted education;

- setting the region's order for the teacher training places financed by the federal budget;

- setting the region's order for personnel training financed by the regional budget;

2) organisational:

- creating educational consortia;

- creating the regional guidance programs and services;

- creating "pedagogical classes" in secondary general education schools;

- developing training and retraining programs for those who have a non-major education (up to one year);

3) content:

- creating an education network based on hub schools;

- integrating the schoolchildren of the region into the system of distance learning provided by a professional educator;

- updating the list and content of advanced training and retraining programs for subject teachers;

- creating pedagogical teams consisting of students learning different subjects to work at educational institutions;

- creating pedagogical e-communities.

The authorities of the RF entities and the Vyatka State University are working at the development and implementation of the above trajectories to develop the pedagogical community. Possible effects, risks, barriers are also investigated by the scientists.

\section{ACKNOWLEDGEMENT}

1. The work is performed according to the Russian Government Program of Competitive Growth of Kazan Federal University.

2. The publication has been prepared with the support of the 'RUDN University Program 5-100'.

\section{REFERENCES}

Ahlander, V., Rydell, R., \& Lofqvist, A. (2011). Speaker's Comfort in Teaching Environments: Voice Problems in Swedish Teaching Staff. Journal of Voice, 25(4), 430-440. https:/ / doi.org/10.1016/j.jvoice.2009.12.006

Aslrasouli, M., Saadat, M., \& Vahid, P. (2014). An Investigation of Teaching Anxiety among Novice and Experienced Iranian EFL Teachers across Gender. Procedia - Social and Behavioral Sciences, 98(5), 304-313. https:// doi.org/10.1016/j.sbspro.2014.03.421

Blömeke, S., \& Delaney, S. (2012). Assessment of teacher knowledge across countries: A review of the state of research. ZDM Mathematics Education, 44, 223-247. https:/ / doi.org/10.1007/s11858-012-0429-7 
Bullough, R. (2015). Differences? Similarities? Male teacher, female teacher: An instrumental case study of teaching in a Head Start classroom. Teaching and Teacher Education, 47(4), 13-21. https://doi.org/10.1016/j.tate.2014.12.001

Burumbayeva, M., Mussina, A., Suleimenova, R., Tebenova, K., Alshynbekova, G., \& Kulov, A. (2018). Status of heart rate variability and hemodynamic parameters of women-teachers according to age. Drug Invention Today, 10(1), 102-107.

Cau-Bareille, D., Teiger, C., \& Volkoff, S. (2019). Revealing the hidden processes behind discrimination against parttime teachers in France: A lever for improving their situation. Proceedings of the 20th Congress of the International Ergonomics Association, 259-268. https:/ / doi.org/10.1007/978-3-319-96065-4_29

Dare, E. A., Ellis, J. A., \& Roehrig, G. H. (2018). Understanding science teachers' implementations of integrated STEM curricular units through a phenomenological multiple case study. International Journal of STEM Education, 5(1). https:/ / doi.org/10.1186/s40594-018-0101-z

Demonty, I., Vlassis, J., \& Fagnant, A. (2018). Algebraic thinking, pattern activities and knowledge for teaching at the transition between primary and secondary school. Educational Studies in Mathematics, 99(1), 1-19. https:/ / doi.org/10.1007/s10649-018-9820-9

Dmitrieva, N. V., Zaitseva, N. A., Kulyamina, O. S., Larionova, A. A., \& Surova, S. A. (2015). Scientific and theoretical aspects of the staff recruitment organization within the concept of "Talent Management". Asian Social Science, 11(3), 358-365. https:// doi.org/10.5539/ass.v11n3p358

Etherington, M. B. (2011). A study of the perceptions and worldviews of mature age pre-service teachers aged between 31 and 53. Journal of Adult Development, 18(1), 37-49. https:/ / doi.org/10.1007/s10804-010-9104-9

Faleeva, L. V., Bratukhina, E. V., Ezhov, S. G., Gorbunova, L. N., Lopanova, A. P., Viaznikova, L. F., \& Kryukova, N. I. (2017). Student's social experience forming in university vocational training, Eurasian Journal of Analytical Chemistry, 12(7), 1127-1135. https:/ / doi.org/10.12973/ ejac.2017.00238a

Fedorov, A. A., Soloviev, M. Yu., Ilaltdinova, E. Yu., Kondratiev, G. V., \& Frolova, S. V. (2018) Age structure of the pedagogical community: analysis and forecast of development: an analytical report, Minin University, 78. Retrieved from http:/ / book.mininuniver.ru

Filatov, V. V., Zaitseva, N. A., Larionova, A. A., Zhenzhebir, V. N., Polozhentseva, I. V., Takhumova, O. V., \& Kolosova, G. M. (2018). State Management of Plastic Production Based on the Implementation of UN Decisions on Environmental Protection. Ekoloji, 106, 635-642.

Firsova, I., Vasbieva, D., Prokopyev, A. I., Zykin, E. S., \& Matvienko, V. V. (2018). Development of consumers' behavior business model on energy market. International Journal of Energy Economics and Policy, 8(4), 227-233.

Freude, G., Seibt, R., Pech, E., \& Ullsperger, P. (2005). Assessment of work ability and vitality-a study of teachers of different age groups. https:/ / doi.org/10.1016/j.ics.2005.02.099

Gampel, D., \& Ferreira, L. (2017). How Do Adolescent Students Perceive Aging Teachers' Voices? Journal of Voice, 31(4), 512.e9-512.e16. https:/ / doi.org/10.1016/j.jvoice.2016.11.021

Gargallo, B., Suárez-Rodríguez, J. M., Almerich, G., Verde, I., Cebrià I., \& Iranzo, M. À. (2018). The dimensional validation of the student engagement questionnaire (SEQ) with a spanish university population. students' capabilities and the teaching-learning environment [Validación dimensional del student engagement questionnaire (SEQ) en población universitaria española. Capacidades del alumno y entorno de enseñanza/aprendizaje]. Anales De Psicologia, 34(3), 519-530. https:/ / doi.org/10.6018/analesps.34.3.299041

Hargreaves, A. (2018). Educational change takes ages: Life, career and generational factors in teachers' emotional responses to educational change. Teaching and Teacher Education, 21(8), 967-983. https:// doi.org/10.1016/j.tate.2005.06.007

Hildebrandt, S., \& Eom, M. (2011). Teacher professionalization: Motivational factors and the influence of age. Teaching and Teacher Education, 27(2), 416-423. https:/ / doi.org/10.1016/j.tate.2010.09.011

Kinnunen, U., Parkatti, T., \& Rasku, A. (1994). Occupational well-being among aging teachers in Finland. Scandinavian Journal of Educational Research, 38(3-4), 315-332. https:/ / doi.org/10.1080/0031383940380312

Kraker-Pauw, E., Wesel, F., Verwijmeren, T., Denessen, E., \& Krabbendam, L. (2016). Are teacher beliefs genderrelated? Learning and Individual Differences, 51(10), 333-340. https:/ / doi.org/10.1016/j.lindif.2016.08.040

Kuo, L., Yang, H., Lin, Y., \& Su, S. (2011). A non-econometric analysis with algebraic models to forecast the numbers of newly hired and retirement of public primary school teachers in Taiwan. Educational Research and Reviews, 6(18), 943-951. https:/ / doi.org/10.5897/ERR11.044 
Kvon, G. M., Lushchik, I. V., Karpenko, M. A., Zaitseva, N. A., Kulkov, A. A., Galushkin, A. A., \& Yakupova, N. M. (2017). Regional investment policy: analysis and assessment of the investment environment state. Eurasian Journal of Analytical Chemistry, 12(5), 835-853. https:/ / doi.org/10.12973/ jac.2017.00215a

Kvon, G. M., Prokopyev, A. I., Shestak, V. A., Ivanova, S. A., \& Vodenko, K. V. (2018). Energy saving projects as energy security factors. International Journal of Energy Economics and Policy, 8(6), 155-160.

Lingo, M. E., Williams-Diehm, K. L., Martin, J. E., \& McConnell, A. E. (2018). Teaching transition self-determination knowledge and skills using the ME! bell ringers. Career Development and Transition for Exceptional Individuals, 41(3), 185-189. https:// doi.org/10.1177/2165143417753582

Lubnina, A. A., Shinkevich, M. V., Ashmarina, S. I., Zaitseva, N. A., Saifutdinova, G. B., \& Ishmuradova, I. I. (2016). Resource saving innovative forms of the industrial enterprises. International Journal of Economics and Financial Issues, 6(2), 479-483.

Lynch, P. (2018). Shadow living: Toward spiritual exercises for teaching. College English, 80(6), 499-516.

McGrath, K., \& Bergen, P. V. (2017). Are male teachers headed for extinction? The 50-year decline of male teachers in Australia. Economics of Education Review, 60, 159-167. https:/ / doi.org/10.1016/j.econedurev.2017.08.003

Ministry of Education and Science of Russia. (2017). Order of the Ministry of Education and Science of Russia №. 955 of September 22, 2017 «On Approval of Educational System Monitoring Indicators».

Moe, Z. H., San, T., Tin, H. M., Hlaing, N. Y., \& Tin, M. M. (2019). Evaluation for teacher's ability and forecasting student's career based on big data. International Conference on Big Data Analysis and Deep Learning Applications, AISC, 20-27. https://doi.org/10.1007/978-981-13-0869-7_3

Mota, B., Giannini, P., Oliveira, I., Paparelli, R., \& Ferreira, L. (2018). Voice Disorder and Burnout Syndrome in Teachers. Journal of Voice, 9. https:/ / doi.org/10.1016/j.jvoice.2018.01.022

Moueleu Ngalagou, P., Assomo-Ndemba, P., Owona Manga, L., Owoundi Ebolo, H., \& Mandengue, S. (2018). Burnout syndrome and associated factors among university teaching staff in Cameroon: Effect of the practice of sport and physical activities and leisures. L'Encéphale, In press, corrected proof, 9. https:// doi.org/10.1016/j.encep.2018.07.003

NGPU. (2016) Pedagogical personnel of the Novosibirsk region: Information system. Retrieved from http:/ / pedkadry.nspu.ru

Novikova, Y. B., Alipichev, A. Y., Kalugina, O. A., Esmurzaeva, Z. B., \& Grigoryeva, S. G. (2018). Enhancement of socio-cultural and intercultural skills of EFL students by means of culture-related extra-curricular events. XLinguae, 11(2), 206-217. https:/ / doi.org/10.18355/XL.2018.11.02.16

Oborsky, A. Y., Chistyakov, A. A., Prokopyev, A. I., Nikolyukin, S. V., Chistyakov, K. A., \& Tararina, L. I. (2018). The national mentality in the history of philosophy. XLinguae, 11(3), 158-165. https:/ / doi.org/10.18355/XL.2018.11.03.15

Oerke, B., \& Bogner, F. X. (2010). Gender, age and subject matter: Impact on teachers' ecological values. Environmentalist, 30(2), 111-122. https:/ / doi.org/10.1007/s10669-009-9250-4

Pedro, L. F. M. G., Barbosa, C. M. M. O., \& Santos, C. M. N. (2018). A critical review of mobile learning integration in formal educational contexts. International Journal of Educational Technology in Higher Education, 15(1), 266278. https:/ / doi.org/10.1186/s41239-018-0091-4

Petrovskaya, M. V., Zaitseva, N. A., Bondarchuk, N. V., Grigorieva, E. M., \& Vasilieva, L. S. (2016). Scientific methodological basis of the risk management implementation for companies capital structure optimization. IEJME - Mathematics Education, 11(7), 2571-2580.

Powell, M., \& Ferraro, C. D. (1960). Sources of tension in married and single women teachers of different ages. Journal of Educational Psychology, 51(2), 92-101. https:/ / doi.org/10.1037/h0041826

Pugach, V. N., \& Utemov, V. V. (2016). Expert-analytical assessment of the age structure of the personnel potential of educational institutions of the Kirov region. Scientific-methodical electronic journal «Concept», 17, $974-986$. Retrieved from http:/ / e-koncept.ru/2016/46371.htm

Roschnik, N., Parawan, A., Baylon, M. A. B., Chua, T., \& Hall, A. (2004). Weekly iron supplements given by teachers sustain the haemoglobin concentration of schoolchildren in the Philippines. Tropical Medicine and International Health, 9(8), 904-909. https:/ / doi.org/10.1111/j.1365-3156.2004.01279

Rosstat. (2016). Order of Rosstat of August 17, 2016 №. 429 «On Approval of Statistical Tools for Organization by the Ministry of Education and Science of the Russian Federation of federal statistical monitoring of the activities of organizations providing training in educational programs of primary general, basic general and secondary general education». Moscow: Rosstat. 
Rosstat. (2018). Rosstat's demographic forecast for the Kirov region for the period up to 2036. Retrieved from http:/ / kirovstat.gks.ru/wps/wcm/connect/rosstat_ts/kirovstat/ru/statistics/population

Rudenko, L., Zaitseva, N., Larionova, A., Chudnovskiy, A., \& Vinogradova, M. (2015). Socio - economic role of service - sector small business in sustainable development of the Russian economy. European Research Studies Journal, 18(3), 223-238.

Sari, M. (2012). Exploring gender roles' effects of Turkish women teachers on their teaching practices. International Journal of Educational Development, 32(6), 814-825. https:/ / doi.org/10.1016/j.ijedudev.2011.08.002

Sasa, C., Borosb, D., \& Bonchisc, E. (2011). Aspects of the burnout syndrome within the teaching staff. Procedia Social and Behavioral Sciences, 11, 266-270. https://doi.org/10.1016/j.sbspro.2011.01.074

Seibt, R., Steputat, A., Spitzer, S., Druschke, D., \& Scheuch, K. (2015). Age-related effects on mental ability and their associations with personal characteristics among female teachers [Altersbez ogene Effekte mentaler Leistungsfähigkeit und deren Zusammenhang zu personenbezogenen Merkmalen bei Lehrerinnen]. Gesundheitswesen, 77(1), 39-45. http:// doi.org/10.1055/s-0034-1367029

Selzer King, A., Jensen, R. E., Jones, C., \& McCarthy, M. J. (2018). Occupational stigma communication: The anticipatory socialization of sex educators. Health Communication, 33(12), 1401-1409. https:/ / doi.org/10.1080/10410236.2017.1353867

Shcherbakov, V. S., Makarov, A. L., Buldakova, N. V., Butenko, T. P., Fedorova, L. V., Galoyan, A. R., \& Kryukova, N. I. (2017). Development of higher education students' creative abilities in learning and research activity. Eurasian Journal of Analytical Chemistry, 12(5), 765-778. https:/ / doi.org/10.12973/ ejac.2017.00209a

Sheridan, M. A., McLaughlin, K. A., Winter, W., Fox, N., Zeanah, C., \& Nelson, C. A. (2018). Early deprivation disruption of associative learning is a developmental pathway to depression and social problems. Nature Communications, 9(1), 153-168. https:/ / doi.org/10.1038/s41467-018-04381-8

TsSP and M. (2017). The number of students, teaching and teaching staff, the potential number of educational organizations of all levels of education: the forecast to 2035. Moscow: TsSP

Tumova, A. (2012). Effects of age and length of professional experience on teacher's attitudes to curricular reform. Central European Journal of Public Policy, 6(2), 84-99.

Wagner, N., Rieger, M., \& Voorvelt, K. (2016). Gender, ethnicity and teaching evaluations: Evidence from mixed teaching teams. Economics of Education Review, 54(10), 79-94. https://doi.org/10.1016/j.econedurev.2016.06.004

Wilson, V., Powney, J., Hall, S., \& Davidson, J. (2006). Who gets ahead?: The effect of age, disability, ethnicity and gender on teachers' careers and implications for school leaders. Educational Management Administration $\mathcal{E}$ Leadershi, 34(2), 239-255. https: / / doi.org/10.1177/1741143206062496

Xu, Di., \& Li, Qiujie. (2018). Gender achievement gaps among Chinese middle school students and the role of teachers' gender. Economics of Education Review, 67(12), 82-93. https://doi.org/10.1016/j.econedurev.2018.10.002

Zaitseva, N. A., Larionova, A. A., Filatov, V. V., Rodina, E. E., Zhenzhebir, V. N., Povorina, E. V., \& Palastina, I. P. (2018). Natural-Resource Potential Management of Region's Territorial Ecosystems Issue. Ekoloji, 106, 495502.

Zaitseva, N. A., Larionova, A. A., Gornostaeva, Zh. V., Malinina, O. Yu., Povalayeva, V. A., Vasenev, S. L., Skrynnikova, I. A., \& Ersozlu, A. (2017). Elaboration of the methodology for assessing the development of managerial competences in university students taught with the use of case-technologies. Eurasia Journal of Mathematics, Science and Technology Education, 13(11), 7339-7351.

Zhou, D., Huang, J., Tang, L., Zhu, Y., Fei, Z., \& Li, Y. (2011). Grey relational analysis of pudong teacher trainingstudying network - though the survey data and grouped under age and gender. Paper presented at the Proceedings of International Conference on Grey Systems and Intelligent Services joint with the 15th WOSC International Congress on Cybernetics and Systems, 121-126. https:/ / doi.org/10.1109/GSIS.2011.6044008

\section{http://www.ejmste.com}

